\title{
Faculty Perceptions Of Moving A Face-To- Face Course To Online Instruction
}

Kari Chiasson, Ed.D., University of North Dakota, USA

Katherine Terras, Ph.D., University of North Dakota, USA

Kathy Smart, Ph.D., University of North Dakota, USA

\begin{abstract}
This qualitative study explores the experiences of 10 faculty members who developed and taught an online course that they had previously taught in a face-to-face classroom. The categories from the data analysis included planning, implementation, and reflection. Within the categories, eight themes emerged from the data. The themes addressed technological support received during online course development, time commitment of faculty, role of faculty member, instructional strategies used within the online course, adjustment of teaching in an online course, synchronous versus asynchronous instruction, faculty member confidence, and control. We drew three conclusions from faculty members' experiences and perceptions.
\end{abstract}

Keywords: Online Course; Course Planning; Online Course Implementation; Faculty Reflection; Faculty Commitment

\section{INTRODUCTION}

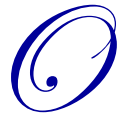

nline instruction in higher education has shown significant growth over the past decade. According to Allen and Seaman (2013), more than 2,800 colleges and universities indicated online learning as critical to the long-term strategic plan. As online education continues to grow, an increasing number of faculty will be asked or even required to prepare curricula and teaching in this environment. Faculty who were earlier adopters have been gaining experience for years; however, many faculty are just beginning to transition their faceto-face courses to teaching in an online environment (Hixon, Buckenmeyer, Barczyk, Feldman, \& Zamojski, 2012).

\section{PURPOSE, RATIONALE, AND RESEARCH QUESTION}

The purpose of this qualitative study was to examine the experiences of faculty members who developed and taught an online course that originated from their recently taught face-to-face course. The rationale for this study was to identify and document faculty members' experiences to inform strategic planning while meeting market demands. The research question that guided this study was, "What are the perceptions of faculty members who developed and taught an online course after teaching it in a face-to-face format?"

\section{REVIEW OF LITERATURE}

According to Allen and Seaman (2013), the number of students taking at least one online course at institutions of higher education totaled 6.7 million. Based on the growth in online enrollments, faculty are being asked to develop and teach online courses. Making the switch from face-to-face instruction to online has posed some emerging issues and concerns for faculty. Thormann and Zimmerman (2012) found that the design of the course and its implementation are two major categories of differences between teaching courses online and face-to-face. Some issues that have been identified include time commitment (Lewis \& Abdul-Hamid, 2006), usage of technology tools and/or learning management systems (De Gagne \& Walters, 2009), implementation of appropriate pedagogical strategies (Brinthaupt, Fisher, Gardner, Raffo, \& Woodward, 2011), and adapting to the role of facilitator (Johnson, 2008). 


\section{DEVELOPMENT SUPPORT AND SERVICES}

Institutional support and services for faculty redesigning face-to-face courses to an online environment vary widely. Depending on the institution, some faculty have great latitude with minimal support whereas some institutions require faculty to participate in training prior to teaching online. Lion and Stark (2010) reported that $80 \%$ of the institutions surveyed either agreed or strongly agreed that faculty are offered some level of support for their online courses.

Collaborations are encouraged by institutions to inspire faculty to partner with others in their discipline or with faculty in other academic departments. Another dimension of collaboration includes the partnerships not only among faculty but also with the institutional informational technology staff and instructional designers. Many faculty are willing to teach online but want institutional support in return (Lion \& Stark, 2010; Taylor \& McQuiggan, 2008).

\section{FACULTY CONSIDERATIONS}

The issues of time and incentives are universal to the conversations and research related to online course development and teaching. In a qualitative, metasynthesis study conducted by De Gagne and Walters (2009), "work intensity" was identified as one of the major themes. Faculty believed they "spent more time on planning, designing, delivering and evaluating online instruction" (p. 581) and thought that their workload increased. According to Boettcher (2006), faculty reported working 60-80 hour weeks while moving a face-to-face class to an online course. Planning, preparing, and teaching online represents more than a paradigmatic shift in the way faculty work; it is initiating new ways to think about learning. As faculty redesign their face-to-face course to online, that process and experience changes them as well.

Faculty members need hands-on experience as they enter the realm of teaching online for the first time. Learning to use technology tools in a proficient manner takes time. For faculty members who have not accomplished a level of comfort and/or proficiency with technology tools, it may have more to do with a lack of time and less to do with opposition (Thormann \& Zimmerman, 2012). Findings from several research studies indicated that technology tools make teaching and learning more accessible and efficient, but rarely are there improvements in learning by simply adding technology (Twigg, 2003). Bishop and White (2007) asserted that technology tools need to be provided by the institution in combination with collaborative support to shift the focus from teaching to learning.

\section{METHOD}

Qualitative methodology was the research design used for this for study. Specifically, phenomenological was employed for participant selection, data collection and data analysis.

\section{Participants}

Ten participants were purposely selected based on their experience and willingness to participate in the study (Creswell, 2013). All participants were employed at a midwestern university and taught in the College of Education and Human Development. One participant taught in the Department of Educational Leadership, one was from the Social Work Department, one was from the Counseling Psychology Department, and seven taught in the Department of Teaching and Learning. All 10 participants met the criteria of having developed and taught an online course that they had previously taught in a face-to-face classroom within the last 3 years. For the majority of the participants, teaching an online course was a relatively new endeavor. Prior to teaching the course online, 7 of the 10 participants received some type of technology training, and all 10 participants accessed assistance from a University level instructional designer to assist with technology related issues. 


\section{Procedure}

The research was conducted with the approval of the University's Institutional Review Board (IRB201210-084). Prior to conducting the interviews, we completed an epoche to set aside our personal experiences of developing and teaching an online course that we had previously taught in a face-to-face classroom. In addition, we intentionally addressed any preconceived notions and biases regarding the phenomenon being studied (Creswell, 2013).

We used an interview protocol (Kvale \& Brinkmann, 2015), consisting of 5 demographic questions and 11 open-ended questions with approximately two probes per question about the development and teaching of the redesigned online course. One of us conducted in-person, semi-structured interviews that lasted from 45 to 75 minutes. She provided interview instructions so that standard procedures were followed. The researcher who conducted the interview was responsible for taking copious notes and transcribing the notes into a transcript. Each interview transcript was assigned a code to maintain confidentiality (e.g., FP1=Faculty Participant \#1). All participants were provided a transcript for verification of accuracy through member checking (Lincoln \& Guba, 1985).

\section{Data Analysis}

We used an inductive process to examine the transcripts of the 10 participant interviews. Reading each transcript multiple times to gain a deeper understanding of the data completed the first step of the data analysis process. Each of us independently read the transcripts multiple times.

We then conducted horizontalization by listing every expression relevant to the experience of the participants (Moustakas, 1994). From each transcript we identified significant phrases, sentences, and quotes that pertained directly to the participants' lived experiences of developing an online course. The next step was to reduce and eliminate the data (Moustakas, 1994). We scrutinized each phrase to determine if it was relevant to the phenomenon. Outlying phrases and vague statements were discarded. We each highlighted discrepancies and a discussion ensued to find consensus. During this step we identified 123 clusters of meaning, which were then collapsed into 28 .

The next step involved "clustering and thematizing" the invariant constituents (Moustakas, 1994, p. 87). We formulated clusters of meaning from the significant statements and phrases and then clustered them into categories or themes that were common to all participants. After we identified the emergent categories of "planning," "implementation," and "reflection," we collaboratively analyzed clusters of meaning for potential themes under each category. The core themes emerged when at least 8 out of 10 participants reported a similar experience while developing the online course. Upon completion of the data analysis, eight themes emerged across three categories (see Table 1). 
Table 1. Thematic Analysis

\begin{tabular}{ll}
\hline \multicolumn{1}{c}{ Categories } & $\begin{array}{l}\text { Themes } \\
\text { Faculty accessed an instructional designer to learn how to effectively use technology to support } \\
\text { their own pedagogy while seeking pedagogical support from colleagues. }\end{array}$ \\
& $\begin{array}{l}\text { Faculty perceived that developing an online course is more time intensive than developing a face- } \\
\text { to-face course; therefore, additional compensation should be received. }\end{array}$ \\
& Faculty roles shifted from the "sage on the stage" to the "guide on the side." \\
& $\begin{array}{l}\text { Faculty included similar face-to-face instructional strategies in their online course using a variety } \\
\text { of technology tools. }\end{array}$ \\
& $\begin{array}{l}\text { Faculty made adjustments while teaching the course based on student understanding and feedback, } \\
\text { as well as on time management. }\end{array}$ \\
& $\begin{array}{l}\text { Instructors who taught synchronously suggested online does not require different instructional } \\
\text { tools largely due to student interaction and discussion being maintained; whereas, instructors who } \\
\text { taught asynchronously felt differently. }\end{array}$ \\
& $\begin{array}{l}\text { As a result of teaching online, faculty increased their confidence and believed they became better } \\
\text { instructors in their face-to-face courses. }\end{array}$ \\
& $\begin{array}{l}\text { Faculty perceived they had less control teaching an online course resulting in students taking more } \\
\text { responsibility in their own learning. }\end{array}$ \\
\hline
\end{tabular}

The fourth step in analyzing the data was to identify overall conclusions regarding the phenomenon experienced by the participants. Three conclusions emerged:

1. When planning, faculty spent ample time with an instructional designer learning the technologies to support their self-identified pedagogy; thus, compensation for course development was perceived as necessary.

2. While implementing their online course, faculty's conceptual framework was their prior face-to-face course; interestingly, for those who delivered it synchronously, online did not require different instructional tools like it did asynchronously.

3. Upon reflection, faculty postulated that online teaching made them more efficient and effective teachers, even with their role shifting to facilitator.

\section{RESULTS}

Below, the themes for each category are presented with supporting evidence.

\section{Category 1: Planning}

Theme 1: Faculty accessed an instructional designer to learn how to use technology effectively to support their own pedagogy while seeking pedagogical support from colleagues. All 10 participants used an instructional designer to assist them in identifying appropriate technology tools that would support student learning in their online course. While some of the participants met with the instructional designer on a weekly basis for 1 to 2 hours across a semester, other participants used them for troubleshooting technology problems. One participant stated, "We met maybe three or four times that first summer. We were also communicating on an as-needed basis via e-mail." Another participant shared how she accessed assistance from an instructional designer within her own department: "Our department has a director of distance education who helps everyone with technology .... she was available every step of the way." Most of the participants reported that the time spent with the instructional designer was focused on exploring tool options or learning how to use the chosen tool. One participant stated, "I lay out the objectives over a semester and then figure out the technology that would be best." All of the participants thought that since they had taught the course face-to-face, their pedagogy was solid but on occasion they would seek out colleagues who had previously transitioned a course to an online format for advice on pedagogical concerns. 
Theme 2: Faculty perceived that developing an online course is more time intensive than developing a face-to-face course; therefore, additional compensation should be received. The participants reported that the time they spent planning, implementing, and communicating with students in their online courses ranged from 2 to 20 hours per week. Most participants shared that it took a significant amount of time to learn the technology and to place content into their course site. One participant stated, "It took a lot of time placing content online as well as learning all the technology involved in Blackboard. It was a huge time investment but well worth it." Another participant stated that teaching an online course "was more work than teaching the course face-to-face" but believed that she "ended up with a quality course."

Among the participants, there were significant discrepancies related to compensation for online course development and most of the participants did not know the amount other faculty were paid. Within this study, two participants received no compensation, one received $\$ 500.00$, two received $\$ 1000.00$, three received $\$ 1500.00$, and two received $\$ 3000.00$. Most of the participants believed that the compensation for their work was adequate; yet two participants thought that the additional work was part of their job. One participant stated, "Persons within our department do not understand the complexity of teaching online. Although I took the money for course development, I felt it was part of my job."

\section{Category 2: Implementation}

Theme 1: Faculty roles shifted from the sage on the stage to the guide on the side. Most of the participants agreed that they experienced a role shift to that of a facilitator or guide on the side when teaching their online course. One participant stated, "In the face-to-face class, we are the sage on the stage. I take the primary role but move to the guide on the side very quickly as students build knowledge. In the online course, I am the guide on the side the entire 16 week course." Another participant shared, "My role feels like it has shifted away from being part of the community of learners. I feel more sidelined in online classes."

Theme 2: Faculty included similar face-to-face instructional strategies in their online course using a variety of technology tools. Of the 10 participants, 8 used their face-to-face course as the framework for their online course. They referenced using the same course objectives, course content, and critical components that were used in their face-to-face course. One participant stated that students in his face-to-face course conducted experiments during class time, whereas in the online course "students conducted the experiments outside of class time," so live (synchronous) sessions could be used for discussion about the activity. Some of the participants declared they wanted best practice to lead the change to online and not to let technology dictate how they taught the course. Yet one participant acknowledged that, at times, the technology drove the pedagogy.

Theme 3: Faculty made adjustments while teaching the course based on student understanding and feedback, as well as on time management. One of the major concerns reported by the participants was the need to provide students with more detail regarding the description of the assignments and clearly sharing the due dates of all assignments. All of the participants provided at least one example of making some type of adjustment while teaching their first online course. Several participants came to the realization that it was unrealistic to take everything (e.g., activities, assignments) from their face-to-face course and put it into their online course.

Theme 4: Instructors who taught synchronously suggested online does not require different instructional tools largely due to student interaction and discussion being maintained; whereas instructors who taught asynchronously felt differently. The participants who taught their online course synchronously reported that, other than learning the technology, they did not see any major differences from teaching the same course in a face-to-face classroom. One participant stated, "Adobe Connect Live allowed me to build a community, and I like being a facilitator of a community." He went on to suggest that "students in [his] online course got to know each other as they shared common concerns and joys while affirming each other." Another participant described how she took what she did in her face-to-face course and replicated it in her online course. Participants who taught asynchronous online courses reported that online instruction was not the same as when they taught their face-to-face course primarily due to issues involving time, organization, and interactions between student and teacher and student to student. 


\section{Category 3: Reflection}

Theme 1: As a result of teaching online, faculty increased their confidence and believed they became better instructors in their face-to-face courses. All participants shared that teaching their first online course was wrought with challenges, but in the end they felt a sense of accomplishment and most believed it informed how they taught all of their courses. Several participants reported how they became more organized, prepared, precise, and used many more features within the Blackboard Learning Management System ${ }^{\circledR}$ resulting in a higher level of confidence. One participant shared, "I have improved compared to the first time I taught the course and do not feel guilty. The difference between how I feel is like day and night. I am not completely satisfied but I did a pretty good job." Nearly all of the participants rated their technology skills higher after teaching the online course. One participant rated herself a 3-4 on a 10-point scale prior to teaching the course, then rated herself a solid 8 afterwards. She explained, "I would definitely say that I am much more confident in the area of technological skills. I am the first to admit that I do not know everything I need to know when it comes to online teaching but I am constantly seeking out new ways to improve." Another participant stated, "Wow! I learned so much about myself as an online instructor. First, I learned that I could actually develop and teach an online course. Second, I gained so much more confidence in myself as an instructor."

Theme 2: Faculty perceived they had less control teaching an online course resulting in students taking more responsibility in their own learning. Several participants suggested they had difficulty establishing and maintaining a sense of control within their online courses. One participant stated, "I have a lot less control, which is a good thing because it hands learning back to the learner where it belongs. The responsibility to learn is on them." Another participant shared her thoughts about teaching her first online course: "The first year I taught the online course, I gave my first D ever. I was really questioning the instruction and interaction of the students. I asked myself, 'What am I doing?' I talked to the student's advisor and was told the student had a history of not putting forth effort in some of her other courses. She told me to relax and helped me put it into perspective. I have to say that the doubt on my part was strong, but you can't do the work for the student either."

\section{DISCUSSION}

Based on the eight themes presented, we drew three conclusions about faculty members' experience from face-to-face to online course delivery.

\section{CONCLUSIONS}

Conclusion 1: When planning, faculty spent ample time with an instructional designer learning the technologies to support their self-identified pedagogy; thus, compensation for course development was perceived as necessary. While all participants agreed that developing an online course was more time intensive, none of them were given release time in any form to plan and design their course. Compensation for development was perceived as necessary, yet there was an inequitable monetary compensation structure within the college, as well as no evidence of alternative compensatory mechanisms, such as a course release or reduction in service expectations.

The majority of planning by the participants was with an instructional designer who assisted in selecting and learning technologies to support pedagogy. Only one participant worked in a department that invested in a fulltime director of distance education position. The others were solely reliant on the University's center for instructional and learning technologies. This center was the only formal support structure for faculty with a focus on teaching them to navigate technology independently. Participants invested time creating frameworks to situate their content for presentation and informally solicit pedagogical consultations from colleagues. In Keengwe and Kidd's (2010) review of the literature, the online instructor's role can be viewed under four categories: pedagogical, social, managerial, and technical. Managing these four roles has given those who teach online significantly more responsibility. Ryan, Hodson-Carlton, and Ali (2004) concluded that infrastructure (i.e., policy, technology partnerships, support systems) must already be in place before moving to an online teaching format. Based on concerns from a study of faculty who transitioned to online teaching, Johnson (2008) recommended that a team of 
experts be developed to share in the responsibility, including content expert (faculty member), web-based pedagogy expert, and a technology expert.

Faculty acceptance of online education is consistently cited as a significant barrier, with many being hesitant due to lack of support, assistance, and training (Allen \& Seaman, 2008). Comparatively, Mills, Yanes, and Casebeer (2009) also conducted a qualitative study of faculty perceptions in a college of education. One of the findings was that administrative support was lacking both with infrastructure and compensation. In this study, participants identified similar temporal, financial, and infrastructural barriers. Participants noted hesitancy to engage in teaching a course online due to their perceptions of these barriers; consequently, leading them to perceive online education as ineffective and/or too labor intensive. Although the participants in our study encountered the aforementioned barriers, they accepted them (e.g., worked for little or no financial payment) or overcame them (e.g., solicited own mentor). Intriguingly, the participants revised their initial perceptions and concluded online education made them better teachers.

De Gagne and Walters (2009) conducted a qualitative metasynthesis of the online teaching experience across nine studies involving 203 participants. All of the studies documented work intensity with planning, designing, delivering, and evaluating online instruction, thus increasing faculty workload. The process of designing and planning online courses is often more time consuming because instructors must provide more detail regarding the process, structure, and evaluation, along with the interactive components of the course (Anderson, Rourke, Garrison, \& Archer, 2001; De Gagne \& Walters, 2009). Results from De Gagne and Walters' (2009) metasynthesis suggested that faculty need to be provided with continuous support that includes appropriate technology, ongoing training, and technical assistance. A confirming finding was drawn from our study. However, what was interesting about the participants in this study was the need for continuous support, yet there was an underlying passivity for improving institutional support.

Conclusion 2: While implementing their online course, faculty's conceptual framework was their prior face-to-face course; interestingly, for those who delivered it synchronously, online did not require different instructional tools like it did teaching asynchronously. The professional literature suggested online courses not only need different instructional and technical tools (Ray, 2009), but also a different type of pedagogy (Bates \& Watson, 2008). From the current study, the opposing viewpoint is that while the pedagogical strategies remained intact during the development and teaching of online courses, it was the medium and instructional tools that changed. To illustrate, modeling is a well-accepted pedagogical strategy that went from a live demonstration in a face-to-face class to a recorded demonstration in the online class. In our study, participants reported how course objectives and accreditation accountability were not altered per learning format; pedagogy remained the independent variable for quality assurance. This was confirmed with the findings in Johnson's (2008) study in that "the conceptual framework, program outcomes, and student learning objectives do not change in web-based education. Students can acquire and synthesize new knowledge in this environment much as they do in a face-to-face classroom" (p. 22).

For those who taught synchronously, instructional styles were comparable to face-to-face instruction regarding how students participated in and led class discussions and presentations. Participants denoted minor alterations, such as a reduction in lecture time. Participants who delivered their courses asynchronously also retained their conceptual, pedagogical framework from face-to-face, but had to use different media and instructional tools for presentation of content and for student interaction. For these reasons, a face-to-face classroom experience is difficult to replicate in the online environment without adjustments (Ray, 2009).

Conclusion 3: Upon reflection, faculty postulated that online teaching made them more efficient and effective teachers, even with their role shifting to facilitator. Because this study was situated in a college of education, most participants were already pedagogical experts, yet online teaching further advanced their skills. They used more explicit instruction for clarity, enhanced content with new instructional tools and aids, and became more intentional about social interaction.

When teaching online, faculty find themselves in the role of learning facilitator rather than lecturer or teacher, and this change is one for which many faculty find themselves unprepared (Vaill \& Testori, 2012). In the 
current study, the shift to facilitator was embraced by most, but uncomfortable for a few. Students taking responsibility for their learning is an expectation of most faculty, yet how that responsibility is operationalized varies from taking leadership roles in content presentation to taking responsibility for studying content presented by the instructor. Based on De Gagne and Walters' (2009) qualitative metasynthesis, one of the most significant changes was in the role from lecturer to guide, from knowledge dispenser to resource provider, and from authority to facilitator. Interestingly, only one faculty member perceived his role as being a facilitator in his face-to-face classes prior to this study. While several faculty employed constructivist principles, they still perceived their role as a being a teacher in the traditional classroom. However, after teaching online, the role of facilitator became more prevalent in their face-to-face classes.

There was also growth in the affective domain of learning. Some participants were able to "let go" or at least "push the boundaries of control" of the variables in online learning (e.g., temporal delays due to technology). Others noted a reduction in anxiety after conquering aspects of online teaching.

Qualitative studies of instructors who teach online are crucial to provide direction for practice and research as they offer an emic perspective (De Gagne \& Walters, 2009). In this study, it was perceived that faculty who transition to teaching an online course from a face-to-face course are pedagogically sound but seek out technology training and require ongoing support while teaching their course. Whereas, they seek collegial support to address concerns related to pedagogy, the faculty role, and logistics of teaching an online course.

\section{RECOMMENDATIONS}

When the need arises for courses to be developed or redesigned for online delivery, the department and/or college needs to establish an equitable workload compensation policy that addresses the additional work required of faculty. Consideration of additional time and effort for receiving technology training, planning, designing, delivering and evaluating online instruction needs to be addressed.

Another recommendation is that a multi-tiered system of support (MTSS) for new and experienced faculty be implemented within the institution. Even though the current infrastructure within the University emphasizes technological acquisition, additional considerations to support faculty through orientation, mentoring, and ongoing support must be addressed. Above all, a robust MTSS needs to offer a variety of services that are supported universally and individually.

A recommendation for future research is to explore institutional support for online teaching by faculty who are in varied fields of study. Further, exploring how academic programs determine and prioritize the development of online courses and the faculty time required to do so. Finally, asertaning if and how institutions recognize online course development in promotion and tenure considerations is germane as remuneration often does not reflect the time required.

\section{AUTHOR INFORMATION}

Dr. Kari Chiasson is an associate professor in the special education program at the University of North Dakota (UND), Department of Teaching and Learning. She holds a bachelor's degree in elementary and special education (visual impairment), a master's degree in special education (early childhood special education) and a doctoral degree in teacher education. Her research interests include online education, faculty development, and education of young children with disabilities and students with blindness and visual impairment. E-mail: kari.chiasson@email.und.edu (Contact author)

Dr. Katherine Terras is an Associate Professor of Teaching and Learning at the University of North Dakota. She holds a bachelors degree in elementary education, a master's degree in special education (with expertise in emotional/behavioral disorders, behavior analysis, and assessment) and a doctoral degree in higher education. Her research interests include distance learning, institutional assessment, and educational outcomes for students with emotional/behavioral disorders. E-mail: katherine.terras@email.und.edu 
Kathy Smart has over 25 years of professional experience as a university administrator and as a faculty member at the University of North Dakota. Currently an Associate Professor in the Department of Teaching and Learning in the College of Education, she teaches graduate and undergraduate courses in technology in higher education and PK-12 teacher preparation. In the teacher preparation program, Dr. Smart teaches courses for early childhood, elementary, secondary and middle school teacher candidates many of whom will student teach and become employed in rural communities upon graduation. E-mail: kathy.smart@email.und.edu

\section{REFERENCES}

Allen, I., \& Seaman, J. (2008, January 1). Staying the course: Online education in the United States. Retrieved from http://olc.onlinelearningconsortium.org/publications/survey/staying_course

Allen, I., \& Seaman, J. (2013). Changing course: Ten years of tracking online education in the United States. Retrieved from http://sloanconsortium.org/publications/survey/changing_course_2012

Anderson, T., Rourke, L., Garrison, D. R., \& Archer, W. (2001). Assessing teaching presence in a computer conferencing context. Journal of Asynchronous Learning Networks, 5(2), 1-17.

Bates, C., \& Watson, M. (2008, March). Re-learning teaching techniques to be effective in hybrid and online courses. Journal of American Academy of Business, 13(1), 38-44.

Bishop, M., \& White, S. (2007). The clipper project: Discovering what online courses offer residential universities. EDUCAUSE Review Online, 30(1), 14-20. Retrieved from https://net.educause.edu

Boettcher, J. (2006). How much does it cost to develop a distance learning course? It all depends ... Retrieved from http://www.designingforlearning.info/services/writing/dlmay.htm

Brinthaupt, T., Fisher, L., Gardner, J., Raffo, D., \& Woodward, J. (2011). What the best online teachers do. Journal of Online Learning and Teaching, 7(4), 515-524.

Creswell, J. (2013). Qualitative inquiry and research design: Choosing among five approaches (3rd ed.). Los Angeles, CA: Sage.

De Gagne, J. C., \& Walters, K. (2009). Online teaching experience: A qualitative metasynthesis (QMS). Journal of Online Learning and Teaching, 5(4), 577-589.

Hixon, E., Buckenmeyer, J., Barczyk, C., Feldman, L., \& Zamojski, L. (2012). Beyond the early adopters of online instruction: Motivating the reluctant majority. Internet and Higher Education, 15(2), 102-107. Retrieved from http://www.sciencedirect .com/science/article/pii/S1096751611000893

Johnson, A. (2008). A nursing faculty's transition to teaching online. Nursing Education Perspectives, 29(1), 17-22.

Keengwe, J., \& Kidd, T. T., (2010, June). Towards best practices in online learning and teaching in higher education. Journal of Online Learning and Teaching, 6(2). Retrieved from http://jolt.merlot.org/vol6no2/keengwe_0610.htm

Kvale, S., \& Brinkmann, S. (2015). InterViews: Learning the craft of qualitative research interviewing (3rd ed.). Thousand Oaks, CA: Sage.

Lewis, C., \& Abdul-Hamid, H. (2006). Implementing effective online teaching practices: Voices of exemplary faculty. Innovative Higher Education, 31(2), 83-98. doi: $10.1007 / \mathrm{s} 10755-006-9010-\mathrm{z}$

Lincoln, Y. S., \& Guba, E. G. (1985). Naturalistic inquiry. Beverly Hills, CA: Sage.

Lion, R., \& Stark, G. (2010). A glance at institutional support for faculty teaching in an online learning environment. EDUCAUSE Quarterly, 33(3). Retrieved from http://www.educause.edu/ero/article/glance-institutionalsupport-faculty-teaching-online-learning-environment

Mills, S. J., Yanes, M. J., \& Casebeer, C. M. (2009). Perceptions of distance learning among faculty of a college of education. Journal of Online Learning and Technology, 5(1), 19-28.

Moustakas, C. (1994). Phenomenological research methods. Thousand Oaks, CA: Sage.

Ray, J. (2009). Faculty perspective: Training and course development for the online classroom. Journal of Online Learning and Teaching, 5(2), 263-276.

Ryan, M., Hodson-Carlton, K., \& Ali, N. S. (2004). Reflections on the role of faculty in distance learning and changing pedagogies. Nursing Education Perspectives, 25(2), 73-80.

Taylor, A., \& McQuiggan, C. (2008). Faculty development programming: If we build it, will they come? EDUCAUSE Quarterly, 31(3),

28-37.

Thormann, J., \& Zimmerman, I. K. (2012). The complete step-by-step guide to designing and teaching online 
courses. New York, NY: Teachers College Press.

Twigg, C. A. (2003). Improving learning and reducing costs: New models for online learning. EDUCAUSE Review, 38(5), 28-38.

Vaill, A. L., \& Testori, P. A. (2012). Orientation, mentoring and ongoing support: A three-tiered approach to online faculty development. Journal of Asynchronous Learning Networks, 16(2), 111-119. 